\title{
Lower air temperature is associated with higher ambulance transports in Sakata area, Yamagata prefecture, Japan
}

\author{
Nobuyuki Miyatake ${ }^{1}$, Tomohiro Hirao ${ }^{2}$, Noriko Sakano ${ }^{1}$, Naoko Tanaka ${ }^{3}$, Hiroshi Kinoshita ${ }^{3}$ \\ ${ }^{1}$ Department of Hygiene, Faculty of Medicine, Kagawa University, Takamatsu, Japan \\ ${ }^{2}$ Department of Public Health, Faculty of Medicine, Kagawa University, Takamatsu, Japan \\ ${ }^{3}$ Department of Forensic Medicine, Faculty of Medicine, Kagawa University, Takamatsu, Japan \\ Email: miyarin@med.kagawa-u.ac.jp \\ Received 21 September 2013; revised 21 October 2013; accepted 30 October 2013 \\ Copyright (C) 2013 Nobuyuki Miyatake et al. This is an open access article distributed under the Creative Commons Attribution Li- \\ cense, which permits unrestricted use, distribution, and reproduction in any medium, provided the original work is properly cited.
}

\begin{abstract}
To investigate the link between low air temperature and ambulance transports in Japan. Data on climate parameters i.e. air temperature, humidity and daylight hours in Sakata area, Yamagata prefecture, Japan, which is northern part (Tohoku) in Japan, was obtained from Japan Meteorological Agency. Monthly data on ambulance transports due to acute disease from 2005 to 2011 was also directly obtained from Sakata area official website, Japan. The relations between air temperature and ambulance transports were evaluated by ecological study. Ambulance transports per day were $10.1 \pm 1.0$ and mean air temperature was $13.0 \pm 8.4\left({ }^{\circ} \mathrm{C}\right)$. Ambulance transports per day were weakly and negatively correlated with mean air temperature, mean of the highest air temperature, mean of the lowest air temperature, the highest air temperature and daylight hours. It was also weakly and positively correlated with mean humidity. However, the relation between ambulance transports and mean air temperature was well estimated by quadratic curve ( $r$ $=0.633, p<0.0001)$. Lower air temperature was closely associated with higher ambulance transports, as well as higher air temperature was associated with higher ambulance transports in Sakata area, Japan.
\end{abstract}

Keywords: Air Temperature; Ambulance Transports; Sakata Area; Ecological Study

\section{INTRODUCTION}

Global warming and its related health problems are well known and have become public health challenge in the world. We have previously proved that global warming was demonstrated in all 47 prefectures of Japan. In addition, higher air temperature was closely associated with higher ambulance transports due to heat stroke in Japan by ecological study [1]. By using daily data, higher air temperature was also closely associated with higher ambulance transports due to heat stroke in Japan [2].

In turn, there are some reports of the link between lower air temperature and higher prevalence of cardiovascular disease [3,4]. In addition, several authors have reported either a U-shaped, V-shaped or J-shaped relationship to describe the effect of air temperature on mortality [5-8]. However, what effects a decrease in air temperature would have on ambulance transports still remains to be investigated in Japan.

In this study, we explored the relationship between ambulance transports due to acute disease and climate parameters i.e. air temperature, humidity and daylight hours in Sakata area, Yamagata, prefecture, Japan, which located in northern part (Tohoku) of Japan by ecological study.

\section{METHODS}

\subsection{Study Area}

Sakata city is located in Yamagata prefecture, Japan. The city has an estimated population of 110,000 and the population density of 180 persons per $\mathrm{km}^{2}$. Sakata has a humid subtropical climate with very warm summers and cool winters. Precipitation is plentiful thought the year, although the months from February to June have somewhat less rainfall $[9,10]$.

\subsection{Ambulance Transports}

Monthly incidence data of ambulance transports due to 
acute disease from 2005 to 2011 in Sakata area, Yamagata prefecture, Japan was obtained from Sakata Area Fire Department Service [11]. The number of ambulance transports due to acute disease per day was used for analysis.

\subsection{Meteorological Parameters}

Monthly meteorological parameters in Sakata area, Yamagata prefecture, Japan for required period were obtained from Japan Meteorological Agency [12]. The observation spot (the city of the prefectural government) was centrally located. Monthly meteorological parameters, that is, mean air temperature $\left({ }^{\circ} \mathrm{C}\right)$, mean of the highest temperature $\left({ }^{\circ} \mathrm{C}\right)$, mean of the lowest air temperature $\left({ }^{\circ} \mathrm{C}\right)$, the highest air temperature $\left({ }^{\circ} \mathrm{C}\right)$, the lowest air temperature $\left({ }^{\circ} \mathrm{C}\right)$, mean humidity $(\%)$, the lowest humidity (\%) and daylight hours (hours per month) were used for analysis.

\subsection{Statistical Analysis}

Data was expressed as mean \pm standard deviation (SD). A simple correlation analysis was used to test the significance of the linear relationship among continuous variables: $p<0.05$ was considered to be statistical significant. In addition, quadratic curve was applied to the link between ambulance transports and climate parameters.

\section{RESULTS}

Data of climate parameters and ambulance transports due to acute disease from 2005 to 2011 in Sakata area, Yamagata prefecture, Japan was summarized in Table 1. Mean air temperature was $13.0 \pm 8.4\left(0.1\right.$ - 27.9) $\left({ }^{\circ} \mathrm{C}\right)$ and ambulance transports per day due to acute disease was $10.1 \pm 1.0(7.2-12.5)$, respectively.

The relationship between ambulance transports per day and climate parameters were evaluated by simple correlation analysis (Table 2). Ambulance transports per day was significantly and weakly correlated with mean air temperature, mean of the highest air temperature, mean of the lowest air temperature, the highest air temperature and daylight hours. Ambulance transports was weakly and positively correlated with the lowest humidity.

However, it is well known that higher air temperature was closely associated with higher ambulance transports $[1,2]$. We estimated the relation between ambulance transports per day and climate parameters by quadratic curve (Table 3, Figure 1). Ambulance transports per day were closely associated with mean air temperature $(\mathrm{r}=$ $\left.0.633, p<0.0001, \mathrm{y}=0.011 \mathrm{x}^{2}-0.317 \mathrm{x}+11.633\right)$, mean of the highest air temperature, mean of the lowest air temperature, the highest air temperature, the lowest air
Table 1. Profiles of climate parameters and ambulance transports from 2005 to 2011 in Sakata area, Japan.

\begin{tabular}{|c|c|c|c|}
\hline & Mean \pm SD & Minimum & Maximum \\
\hline Number of month & 84 & & \\
\hline Mean air temperature $\left({ }^{\circ} \mathrm{C}\right)$ & $13.0 \pm 8.4$ & 0.1 & 27.9 \\
\hline $\begin{array}{l}\text { Mean of the highest air } \\
\text { temperature }\left({ }^{\circ} \mathrm{C}\right)\end{array}$ & $16.8 \pm 8.9$ & 2.4 & 31.8 \\
\hline $\begin{array}{l}\text { Mean of the lowest air } \\
\text { temperature }\left({ }^{\circ} \mathrm{C}\right)\end{array}$ & $9.4 \pm 8.3$ & -2.3 & 24.5 \\
\hline The highest air temperature $\left({ }^{\circ} \mathrm{C}\right)$ & $23.4 \pm 8.6$ & 6.3 & 37.1 \\
\hline The lowest air temperature $\left({ }^{\circ} \mathrm{C}\right)$ & $4.7 \pm 7.9$ & -6.5 & 23.0 \\
\hline Mean humidity (\%) & $72.3 \pm 4.0$ & 62.0 & 85.0 \\
\hline The lowest humidity (\%) & $31.0 \pm 8.8$ & 10.0 & 50.0 \\
\hline $\begin{array}{l}\text { Daylight hours } \\
\text { (hours per month) }\end{array}$ & $124.4 \pm 59.9$ & 22.9 & 250.8 \\
\hline $\begin{array}{l}\text { Ambulance transports due to } \\
\text { acute disease (per month) }\end{array}$ & $307.0 \pm 33.6$ & 224.0 & 386.0 \\
\hline $\begin{array}{l}\text { Ambulance transports due to } \\
\text { acute disease (per day) }\end{array}$ & $10.1 \pm 1.0$ & 7.2 & 12.5 \\
\hline
\end{tabular}

Table 2. Simple correlation analysis between ambulance transports per day and climate parameters.

\begin{tabular}{ccc}
\hline & $\mathrm{r}$ & $p$ \\
\hline Mean air temperature $\left({ }^{\circ} \mathrm{C}\right)$ & -0.281 & $\mathbf{0 . 0 0 9 7}$ \\
Mean of the highest air temperature $\left({ }^{\circ} \mathrm{C}\right)$ & -0.302 & $\mathbf{0 . 0 0 5 2}$ \\
Mean of the lowest air temperature $\left({ }^{\circ} \mathrm{C}\right)$ & -0.256 & $\mathbf{0 . 0 1 8 7}$ \\
The highest air temperature $\left({ }^{\circ} \mathrm{C}\right)$ & -0.352 & $\mathbf{0 . 0 0 1 0}$ \\
The lowest air temperature $\left({ }^{\circ} \mathrm{C}\right)$ & -0.197 & 0.0723 \\
Mean humidity $(\%)$ & 0.050 & 0.6527 \\
The lowest humidity $(\%)$ & 0.268 & $\mathbf{0 . 0 1 3 7}$ \\
Daylight hours (hours per month) & -0.371 & $\mathbf{0 . 0 0 0 5}$ \\
\hline
\end{tabular}

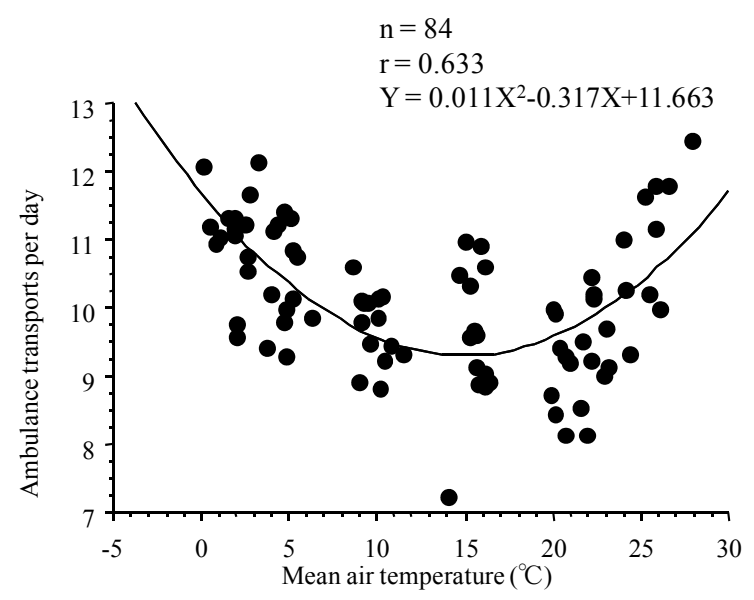

Figure 1. Estimation of the relation between mean air temperature and ambulance transports due to acute disease by quadratic curve in Sakata area, Yamagata prefecture, Japan. 
Table 3. Approximation by quadratic curve between ambulance transports per day and climate parameters.

\begin{tabular}{cccc}
\hline & $\mathrm{r}$ & $p$ & Quadratic curve $(\mathrm{Y}$ : ambulance transports, $\mathrm{X}$ : Climate parameters) \\
\hline Mean air temperature $\left({ }^{\circ} \mathrm{C}\right)$ & 0.633 & $<\mathbf{0 . 0 0 0 1}$ & $\mathrm{Y}=0.011 \mathrm{X}^{2}-0.317 \mathrm{X}+11.633$ \\
Mean of the highest air temperature $\left({ }^{\circ} \mathrm{C}\right)$ & 0.628 & $<\mathbf{0 . 0 0 0 1}$ & $\mathrm{Y}=0.009 \mathrm{X}^{2}-0.342 \mathrm{X}+12.535$ \\
Mean of the lowest air temperature $\left({ }^{\circ} \mathrm{C}\right)$ & 0.625 & $<\mathbf{0 . 0 0 0 1}$ & $\mathrm{Y}=0.011 \mathrm{X}^{2}-0.263 \mathrm{X}+10.794$ \\
The highest air temperature $\left({ }^{\circ} \mathrm{C}\right)$ & 0.506 & $\mathbf{0 . 0 0 0 3}$ & $\mathrm{Y}=0.006 \mathrm{X}^{2}-0.295 \mathrm{X}+13.487$ \\
The lowest air temperature $\left({ }^{\circ} \mathrm{C}\right)$ & 0.593 & $<\mathbf{0 . 0 0 0 1}$ & $\mathrm{Y}=0.011 \mathrm{X}^{2}-0.160 \mathrm{X}+9.949$ \\
Mean humidity $(\%)$ & 0.174 & 0.1307 & $\mathrm{Y}=-0.006 \mathrm{X}^{2}+0.955 \mathrm{X}-24.916$ \\
The lowest humidity $(\%)$ & 0.268 & 0.8511 & $\mathrm{Y}=-0.0002 \mathrm{X}^{2}+0.045 \mathrm{X}+8.922$ \\
Daylight hours (hours per month) & 0.502 & $\mathbf{0 . 0 0 0 7}$ & $\mathrm{Y}=0.0001 \mathrm{X}^{2}-0.03 \mathrm{X}+11.990$ \\
\hline
\end{tabular}

temperature and daylight hours. The correlation coefficient between mean air temperature and ambulance transports per day was the highest among variables. Finally, from the regression line, a $14.4^{\circ} \mathrm{C}$ in mean air temperature was corresponded to a change point of ambulance transports per day.

\section{DISCUSSION}

The main finding of this study was to explore the link between ambulance transports due to acute disease and low air temperature in Sakata area, Yamagata prefecture, Japan by ecological study.

Although direct effects of low air temperature are only in part of the result of increased stress on the circulatory system [8], low air temperature was associated with higher mortality rates form myocardial infarction by retrospective analysis in Northern Ireland [4]. According to the relation between air temperature and total mortality, Braga et al. showed that, in cold cities in US, both high and low air temperature were associated with increased death. The effect of cold air temperatures persisted for days and no clear humidity effect was observed [6]. In this study, we firstly evaluated the link between ambulance transports due to acute disease and air temperature in Sakata area, Yamagata prefecture, Japan. Lower air temperature was closely linked to higher ambulance transports, as well as higher air temperature was linked to higher ambulance transports by using monthly data [1,2]. In addition, the correlation coefficient between mean air temperature and ambulance transports due to acute disease was the highest among variables by estimation of quadratic curve, and a $14.4^{\circ} \mathrm{C}$ in mean air temperature was corresponded to a change point of ambulance transports by quadratic curve. These findings suggest that we need to pay attention to dealing with the relation between low air temperature and its related health conditions as well as high air temperature.

In turn, we have previously proved that positive changes in air temperature were noted and these were accelerated in all 47 prefectures of Japan $[1,13]$. Wanitschek et al. reported that the average air temperature increase of $7.5^{\circ} \mathrm{C}$ from the cold to the warm winter was associated with a decrease in acute coronary angiographies, in particular due to a lower incidence of ST elevation myocardial infarctions [3]. Martens reported that global climate change was likely to read to a reduction in mortality rates due to decreasing winter mortality and this effect is the most pronounced for cardiovascular mortality in elderly people in cities who experience temperate or cold climates at present [7]. Doyon et al. reported that the summer increase and the annual mortality range from about $2 \%$ and $0.5 \%$ for the 2020 period, to $10 \%$ and $3 \%$ for the years around 2080 in Quebec, Canada [14]. Taken together, analysis of any climatic change also should take into account low air temperature-related health problems in future.

Potential limitations still remain in this study. First, we used an ecological study. The link between ambulance transports due to acute disease and air temperatures, which was noted in this study, may not apply for the link among individuals. Second, detailed daily and individual (i.e. age and sex) data of ambulance transports due to acute disease could not be obtained and analyzed in this study. Therefore, we could not evaluate the link between ambulance transports and air temperatures as accurately as we wished. Further ongoing studies are urgently required to prove such a link.

\section{REFERENCES}

[1] Murakami, S., Miyatake, N. and Sakano, N. (2012) Changes in air temperature and its relation to ambulance transports due to heat stroke in all 47 prefectures of Japan. Journal of Preventive Medicine and Public Health, 45, 309-315.

[2] Miyatake, N., Sakano, N. and Murakami, S. (2011) The higher air temperature was closely associated with higher 
ambulance transports due to heat stroke in elderly Japanese. Open Journal of Epidemiology, 1, 1-4.

[3] Wanitschek, M., Ulmer, H., Sussenbacher, A., Dorler, J., Pachinger, O. and Alber, H.F. (2013) Warm winter is associated with low incidence of ST elevation myocardial infarctions and less frequent acute coronary angiographies in an alpine country. Herz, 38, 163-170.

[4] Crawford, V.L., McCann, M. and Stout, R.W. (2003) Changes in seasonal deaths from myocardial infarction. QJM, 96, 45-52.

[5] Pattenden, S., Nikiforov, B. and Armstrong, B.G. (2003) Mortality and temperature in Sofia and London. Journal of Epidemiolgy \& Community Health, 57, 628-633.

[6] Braga, A.L., Zanobetti, A. and Schwartz, J. (2001) The time course of weather-related deaths. Epidemiology, 12, 662-667.

[7] Martens, W.J. (1998) Climate change, thermal stress and mortality changes. Social Science \& Medicine, 46, 331334.

[8] Kunst, A.E., Looman, C.W. and Mackenbach, J.P. (1993) Outdoor air temperature and mortality in the Netherlands: A time series analysis. American Journal of Epidemiology, 137, 331-341.

[9] Sakata City. Yamagata prefecture, Japan official web site
(2013) Sakata City. http://www.city.sakata.lg.jp/ou/kikaku/joho/tokei/2802.ht $\underline{\mathrm{ml}}$

[10] Sakata, Yamagata, Japan (2013). http://en.wikipedia.org/wiki/Sakata,_Yamagata

[11] Annual Report of Fire Disaster Management in Sakata, Yamagata prefecture, Japan (2013) Monthly data of ambulance transports.

http://www.city.sakata.lg.jp/ou/koikigyosei/syobo/soumu/ toukei.html

[12] Japan Meteorological Agency, Japan (2013) Monthly annual climate parameters in Sakata area, Yamagata prefecture, Japan.

http://www.data.jma.go.jp/obd/stats/etrn/index.php?prec no $=35 \&$ block no $=47587 \&$ year $=\&$ month $=\&$ day $=\&$ view $=$

[13] Miyatake, N., Sakano, N., Murakami, S., Suna, S., Suzue, T. and Hirao T. (2011) Comparison of the changes in temperatures among rural, urban and metropolitan areas around the Inland Sea in Japan. Environmental Monitoring and Assessment, 181, 525-530.

[14] Doyon, B., Belanger, D. and Gosselin P. (2008) The potential impact of climate change on annual and seasonal mortality for three cities in Quebec, Canada. International Journal of Health Geographics, 22, 23. 